\title{
Analysis of fishing activity in the Itá reservoir , Upper Uruguay River, in the period 2004-2009
}

\author{
Schork $^{1,2 *}$, G., Hermes-Silva², S. and Zaniboni-Filho ${ }^{2}$, E. \\ ${ }^{1}$ Programa de Pós-Graduação em Aquicultura, Centro de Ciências Agrárias - CCA, \\ Universidade Federal de Santa Catarina - UFSC, CEP 88034-001, Florianópolis, SC, Brazil \\ ${ }^{2}$ Laboratório de Biologia e Cultivo de Peixes de Água Doce - LAPAD, Universidade Federal de Santa Catarina - UFSC, \\ Florianópolis, SC, Brazil \\ *e-mail: gianschork@gmail.com
}

Received June 13, 2012 - Accepted August 19, 2012 - Distributed August 31, 2013

(With 7 figures)

\begin{abstract}
This study characterized fishing activity in the reservoir of the Hydroelectric Power Plant of Itá in Brazil. The reservoir is located in the Upper Uruguay River, which forms the border between the states of Santa Catarina and Rio Grande do Sul. To analyze fishing activity and the composition of ichthyofauna in the reservoir after damming, questionnaires were administered to fishermen in the region between 2004 and 2009. The results showed that fishing in the Itá reservoir can be classified as a subsistence activity performed on small vessels and usually involving the use of drift nets and handlines. Between 2004 and 2009, 292,780.10 kg worth of fish were captured, with an average annual productivity of $3.46 \mathrm{~kg} \mathrm{ha}^{-1} \mathrm{yr}^{-1}$. We recorded the highest values of catch per unit effort in 2006, with an annual average of $9.69 \mathrm{~kg}$ fisherman $^{-1}$ day $^{-1}$. A total of 27 morphospecies were captured during the sample period; carp, traíra, mandi and jundiá together accounted for almost $60 \%$ of the catch. This finding indicates that fishing is centered on the capture of sedentary and short-distance migratory species. Despite their lower abundance, long-distance migratory species continue to be captured. The case of the piracanjuba, a long-distance migratory species reintroduced to the region in 2004 and still present in the catches, is particularly noteworthy. Regarding the fishermen's socioeconomic profile, all were men, most of who have engaged in the activity for more than eleven years, have a low educational level, fish with the aid of family members and list agriculture as their main economic activity.
\end{abstract}

Keywords: fishing resources, dams, inland fishing.

\section{Caracterização da pesca no reservatório de Itá, região do alto Rio Uruguai, no período 2004-2009}

\section{Resumo}

O presente trabalho caracterizou a pesca no reservatório da Usina Hidrelétrica de Itá, localizado na região do Alto Rio Uruguai, divisa entre os Estados de Santa Catarina e Rio Grande do Sul. Procurando descrever a pesca no reservatório, assim como a composição ictiofaunística ao longo dos anos após o represamento, foram aplicados questionários aos pescadores da região entre os anos de 2004 e 2009. Os resultados mostraram que a pesca no reservatório de Itá pode ser enquadrada como de subsistência, realizada por embarcações de pequeno porte e normalmente com o uso de redes de emalhe e linha de mão. Entre os anos de 2004 e 2009 foi registrada a captura de 292.780,10 kg de pescado, com uma produtividade média anual de $3,46 \mathrm{~kg} \mathrm{ha}^{-1} \mathrm{ano}^{-1}$. Foram registrados os maiores valores de Captura Por Unidade de Esforço em 2006, com médias anuais de 9,69 $\mathrm{kg}_{\text {pescador }}{ }^{-1} \mathrm{dia}^{-1}$. Um total de 27 morfoespécies foram capturadas, com destaque para a carpa, a traíra, o mandí e o jundiá que juntas somaram quase $60 \%$ do total capturado ao longo do período estudado, indicando que a pesca está centrada na captura de espécies sedentárias e migradoras de curtas distâncias. Apesar da menor abundância, as espécies migradoras continuam sendo capturadas ao longo dos anos, em especial a piracanjuba, que foi reintroduzida na região em 2004 e que continua presente nas capturas. Em relação ao perfil socioeconômico, os pescadores são todos homens que em sua maioria, estão há mais de 11 anos na atividade, possuem baixo grau de instrução, desenvolvem a pesca com auxílio dos demais membros da família e têm a agricultura como principal atividade econômica.

Palavras-chave: recursos pesqueiros, represamentos, pesca continental. 


\section{Introduction}

In Brazil, more than seven hundred reservoirs have been built in major river basins for power generation (ANEEL, 2008). As a result, almost all the major rivers are now affected by dams (Agostinho et al., 2008).

Disruption of water courses through dam construction has transformed regional hydrological characteristics of the ecosystem, causing profound changes mainly in the composition of fish species and promoting a relatively long period of instability in the new environment (Zaniboni-Filho et al., 2008).

The ichthyic community and fishing activity in areas influenced by hydroelectric plants in southern Brazil have been studied by several authors in recent decades (Okada et al., 1997; Agostinho and Gomes, 2005; Luiz et al., 2005; Beux and Zaniboni-Filho, 2008; Meurer, 2010; Novaes and Carvalho, 2011). The relationship between the damming of the large rivers and subsequent changes in the fish fauna and the ecological and social characteristics of the areas has also been discussed. The construction of dams alters the structure of the fish fauna, allowing the proliferation of some species and the reduction or even elimination of others (Araya et al., 2009; Agostinho et al., 2008).

In general, inland fishing is a small-scale, dispersed activity with no landing control. A lack of consistent guidelines, among other problems, makes this a difficult industry to control (Agostinho et al., 2007; Penha and Mateus, 2007).

Continuous monitoring of fishing activity helps to fill this gap and provides important information for assessing the effects produced by the reservoirs, thus contributing to the development of new conservation strategies and generating subsidies to ensure appropriate management of the natural resources. With this perspective, this study assessed fish production and the socioeconomic aspects of fishing activity in the reservoir of the Hydroelectric Power Plant of Itá in the upper Uruguay River.

\section{Material and Methods}

\subsection{Study area}

The study was conducted in the reservoir of the Hydroelectric Power Plant (HPP) of Itá, which is located in the Upper Uruguay River in Brazil. The river serves as the border between the states of Santa Catarina and Rio Grande do Sul. The dam of HPP Itá is located at latitude $27^{\circ} 16^{\prime} 39^{\prime \prime} \mathrm{S}$ and longitude $52^{\circ} 22^{\prime} 56^{\prime \prime} \mathrm{O}$ (Figure 1) and forms a reservoir with an average depth of $36 \mathrm{~m}$ and a maximum depth of $125 \mathrm{~m}$. The lake, which has a perimeter of approximately $800 \mathrm{~km}$ and a total area of 14,100 ha, borders the municipalities of Itá, Concórdia, Alto Bela Vista and Piratuba in Santa Catarina and Aratiba, Mariano Moro, Severiano de Almeida and Marcelino Ramos in Rio Grande do Sul.

Information on fish production in the reservoir was obtained from fishermen in the two states bordering the
Uruguay River who had an interest in collaborating in the study. The fishermen were trained to complete standardized forms regarding their catches. These forms contained previously tested closed questions, seeking the following detailed information: date; morphospecies captured; number and biomass of each morphospecies; equipment used (drift nets, lines, longlines and cast nets); fishing site (margin, body of the reservoir and arm); and fishing duration (6, 12, 18 and 24 hours). Regarding duration, we considered the morning or afternoon shifts to be 6 hours, the night or day shift to be 12 hours and the sum of night and morning or night and afternoon shifts to be 18 hours and the sum of night and day shifts to be 24 hours. Of note, fishing line equipment included the variations angle, handline and angle reel. The fishing sites were characterized as follows: margin was the region where the fishermen engaged in shore-based fishing; body of the reservoir was the pelagic environment in which fishing boats were used; and arm was a river that drained directly into the reservoir where fishing could be carried out in either a pelagic area or at the margins. The biomass of harvested species was estimated by the fishermen themselves.

To facilitate the identification of fish and completion of the fishing data, the guide "Catálogo Ilustrado de Peixes do Alto Rio Uruguai" by Zaniboni-Filho et al. (2004) was distributed to the fishermen. Use of the catalog contributed to standardization of the information and increased interactions between the interviewer and the fishermen. For further analysis, fish were grouped into morphospecies by common names as well as by the species names listed in the catalog.

Monitoring of fishing activity started in 2004, four years after filling of the reservoir; capture information was collected from 2004 to 2009. Forms recording monthly capture data were collected every two months and were verified with the fishermen to confirm the results and to dispel doubts.

We analysed the fishing activity in Itá reservoir considering the number of fishermen participating in the survey, the number of fishing events for each compartment, the number of equipments used in each fishing event and the duration of the fishing events.

Fish were measured by catch per unit effort (CPUE) and calculated using the biomass captured of each morphospecies recorded for each fisherman per fishing day $\left(\mathrm{kg}\right.$ fisherman ${ }^{-1}$ day $\left.^{-1}\right)$. The CPUE for the three compartments formed by the reservoir (i.e., margin, body of the reservoir and arm) was calculated using the biomass captured in each compartments during the years 2007 to 2009 and was expressed as the daily biomass caught by each fisherman in each of the fishing compartments $\left(\right.$ CPUE $(\mathrm{c})=\mathrm{kg}$ fisherman ${ }^{-1}$ day $^{-1}$ compartment $\left.^{-1}\right)$. The CPUE for the two most common types of equipment used (CPUE (e)) was calculated for the most frequently captured morphospecies and was expressed as the number of fish captured by each fisherman per equipment per fishing day (no.fish fisherman ${ }^{-1}$ equipment ${ }^{-1}$ day $^{-1}$ ) for the years 2007 to 2009 . Information regarding compartments 


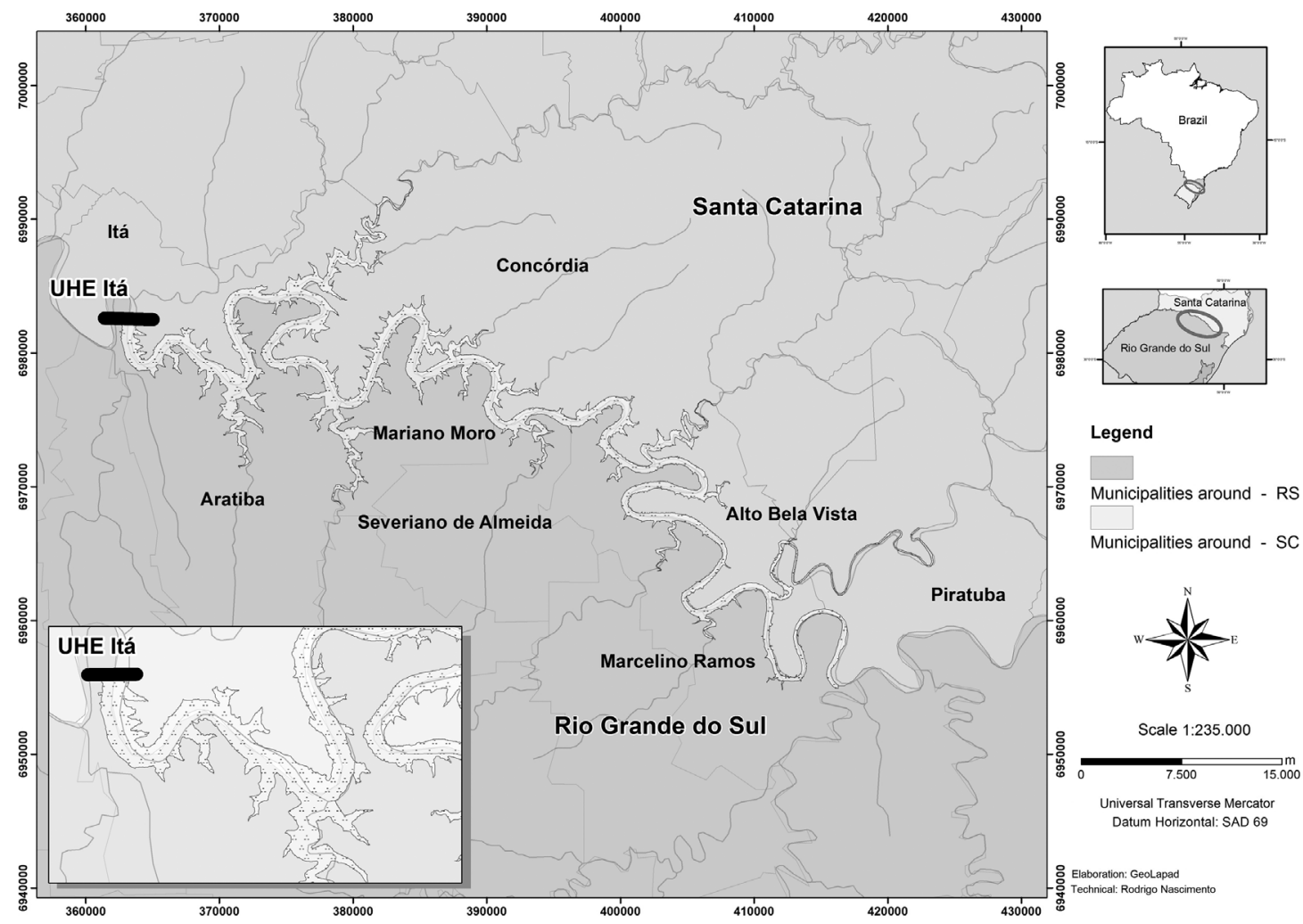

Figure 1 - Location of the reservoir and dam of the Hydroelectric Power Plant of Itá on the Uruguay River between the states of Santa Catarina and Rio Grande do Sul, including municipalities around the lake.

and fishing equipment became part of the questionnaire beginning in 2007 . We also analyzed the composition and temporal variation of the total fishing capture in the region affected by the Itá reservoir.

To evaluate differences between the number of fishing events per compartments, the number of fishing equipments used per fishing event, the duration of the fishing events in each year and the catch per unit effort (CPUE), the Kruskal-Wallis non-parametric analysis was applied. The Dunn test, a posteriori test of multiple comparisons among the ranks, was applied to detect differences between groups.

During the study period, ninety-nine fishermen participated in the survey and provided information on their fishing activities. According to the MPA (2011), two hundred forty-five fishermen were registered in the region of the Itá reservoir, and of this number, only nineteen were respondents in this study. Knowing that survey respondents enrolled in the MPA represented $7.76 \%$ of the legally registered fishermen in the area, we estimated that a total of 1276 fishermen were engaged in fishing activity in the reservoir of HPP Itá, whether registered with the MPA or not. This proportion between the respondents of this study and the fishermen registered in the MPA allowed us to estimate production values in the reservoir.

Socioeconomic data were collected only when fishermen began their participation in the research and con- sisted of a form with open and closed questions on the following topics: complementary professional activities, education, age, marital status, personal consumption and sale of the fish, work relations, etc. Thus, we sought to characterize the people involved in fishing activity in the region and identify their problems and concerns.

\section{Results}

\subsection{Fishing activity}

All the fishing vessels (69) used were small and lacked housing; $82.6 \%$ were made of wood, and $17.4 \%$ were made of aluminum. Propulsion was mostly (83.3\%) obtained using a paddle. Among the motorboats, power ranged from 4 to $25 \mathrm{HP}$, with $25 \mathrm{HP}$ being the modal value.

The number of fishing events analysed as well as the number of fishermen who provided information and tha total biomass captured differed over the years. This variation is presented in Table 1 .

For the three compartments formed by the reservoir (i.e., margin, body of the reservoir and arm), the number of fishing events in each compartment was similar $(p>0.05)$ in 2007. Nevertheless, in the years 2008 and 2009, fishing was carried out primarily in the margins and in the body of the reservoir $(\mathrm{p}<0.05)$ (Figure 2). 
Among the fishing equipment used between 2007 and 2009, the drift net stands out compared with other equipment $(p<0.05)$, although the line was used similar to that of the drift net $(\mathrm{p}>0.05)$ (Figure 3).

The most commonly used mesh size $(22.9 \%)$ was $5.0 \mathrm{~cm}$ between opposite knots, but the size ranged from 1.0 to $15.0 \mathrm{~cm}$ between knots.

The duration of the fishing events showed no significant difference $(p>0.05)$ in the initial year of data collection or in the last two years. In 2005 and 2006, events lasting 6 and 12 hours were more common than events lasting 24 hours $(p<0.05)$. In 2007, the number of 12-hour events was greater than the number of 18- and 24 -hour events $(p<0.05)$ but was equal to the number of 6-hour events (Figure 4).

The number of 6-hour fishing events was significantly different only between the year $2008(\mathrm{p}<0$.05) and the years 2005 and 2009. The number of 12-hour events differed between 2007 and the other years, being equal only to 2008 . However, the preference for 18 -hour events did not differ between years $(\mathrm{p}>0.05)$. The num-

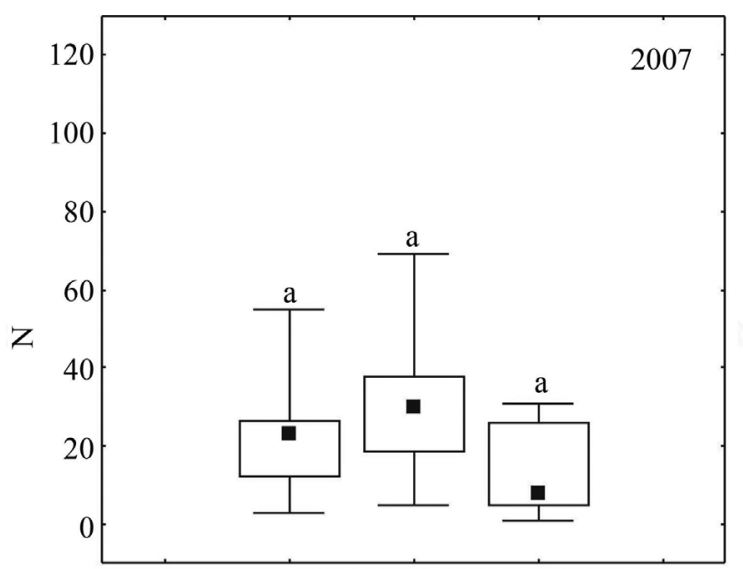

Margins Body of reservoir Arms Compartments
Table 1 - The number of fishing events, the number of fishermen participating in the fishing events, and the total biomass captured for the years 2004 to 2009.

\begin{tabular}{lccc}
\hline Year & $\begin{array}{c}\text { No. of fishing } \\
\text { events }\end{array}$ & $\begin{array}{c}\text { No. of } \\
\text { fishermen }\end{array}$ & $\begin{array}{c}\text { Total capture } \\
\text { (kg) }\end{array}$ \\
\hline 2004 & 367 & 39 & $2.303,12$ \\
2005 & 315 & 31 & $2.408,78$ \\
2006 & 374 & 29 & $3.625,07$ \\
2007 & 779 & 62 & $4.451,66$ \\
2008 & 972 & 74 & $5.818,35$ \\
2009 & 887 & 74 & $4.112,76$ \\
\hline
\end{tabular}

ber of 24-hour events differed significantly only between 2005 and 2009; the numbers of 24-hour events in the other years were equal (Figure 5).

Between 2004 and 2009, the capture of $292,780.10 \mathrm{~kg}$ of fish was recorded. The average fish

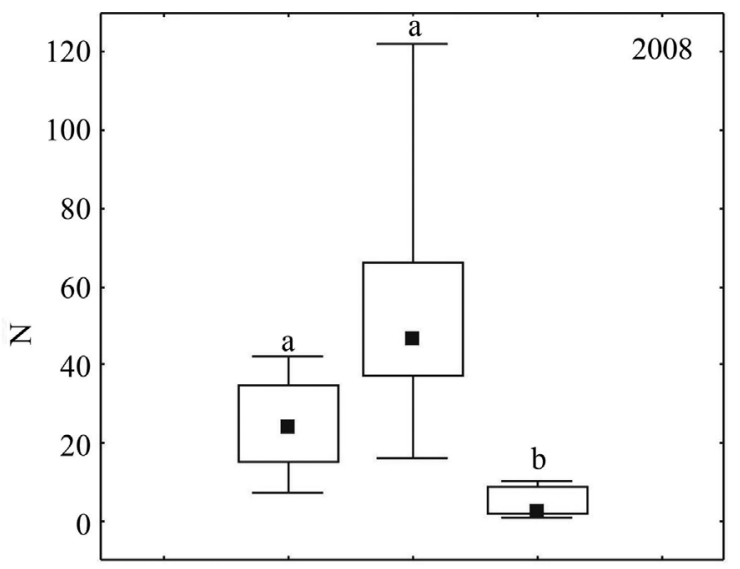

Margins Body of reservoir Arms

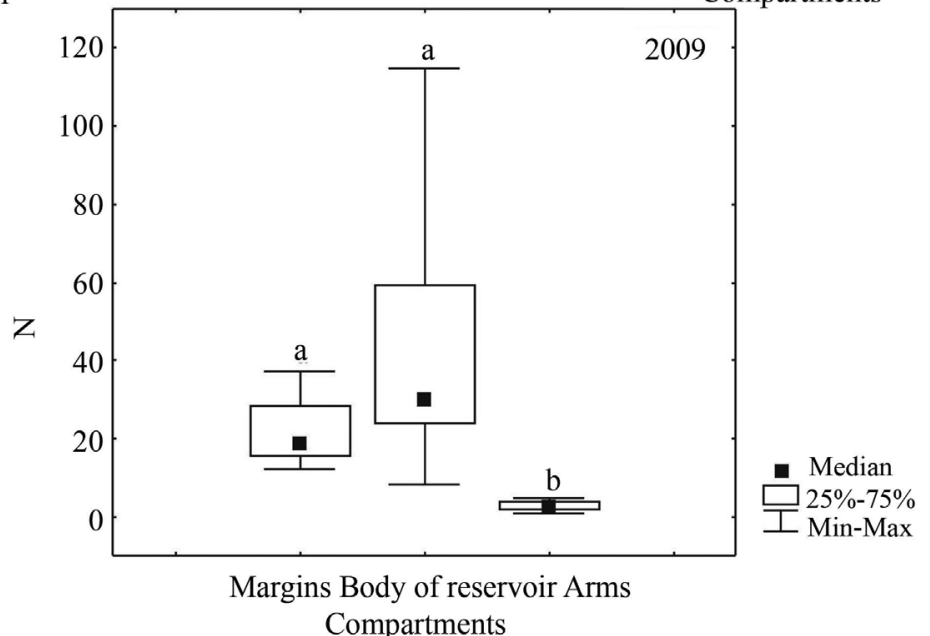

Figure 2 - Comparison of the number of fishing events (N) for 2007, 2008 and 2009 in the three compartments formed by the Itá reservoir. 


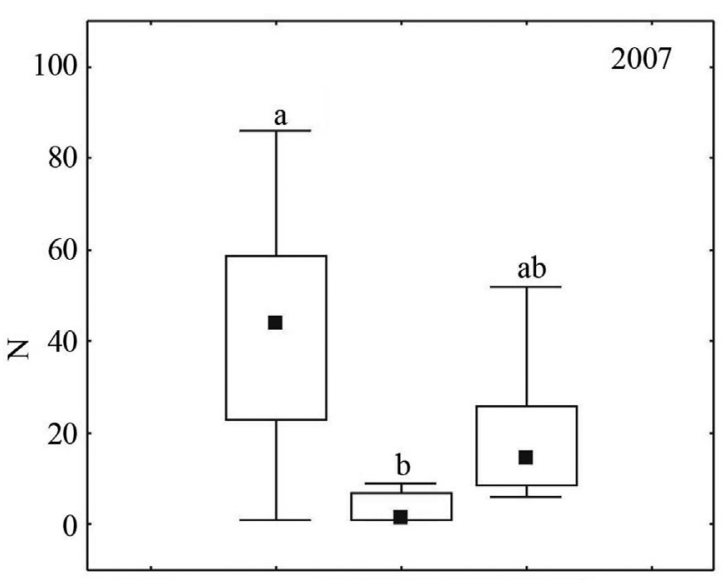

Driftnet Longline Castnet Line Equipament

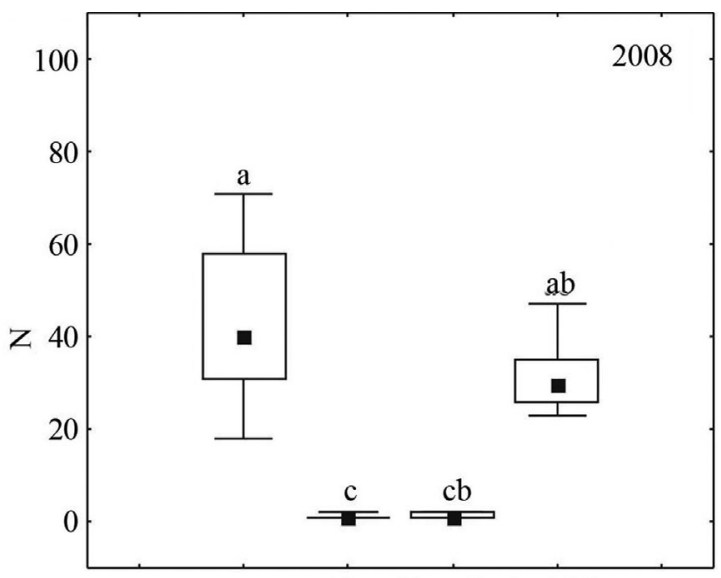

Driftnet Longline Castnet Line Equipament

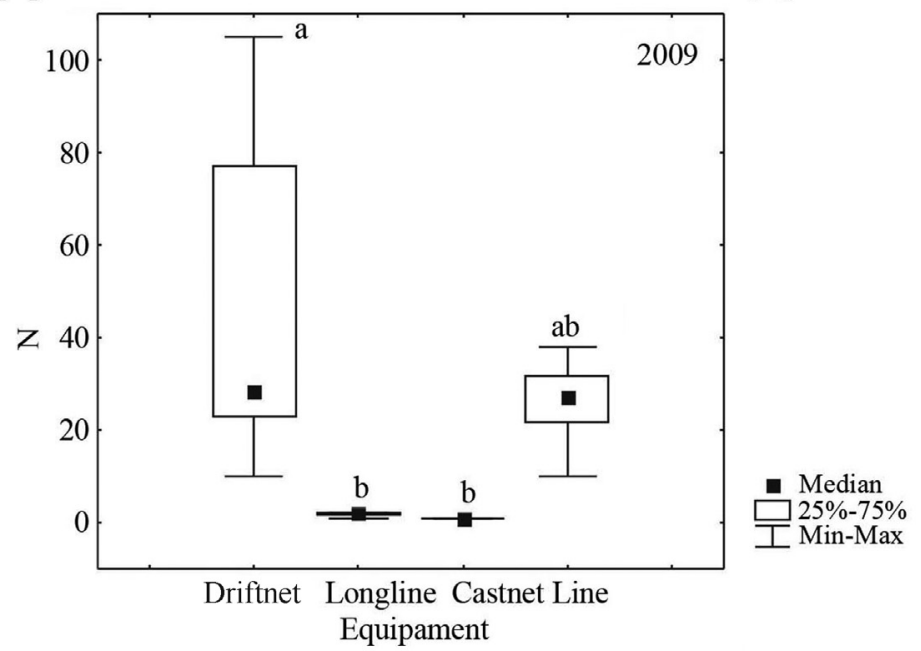

Figure 3 - Comparison of the number of fishing equipments used per fishing event (N) in the Itá reservoir for 2007, 2008 and 2009.

productivity in the Itá reservoir over the entire study period and the total area of the reservoir was $3.46 \mathrm{~kg} \mathrm{ha}^{-1}$ year $^{-1}$ (Figure 6).

The highest values of CPUE were recorded in 2006, with an annual average of $9.69 \mathrm{~kg}$ fisherman ${ }^{-1}$ day $^{-1}$; the lowest values were recorded in 2009, with an average of $4.64 \mathrm{~kg}$ fisherman ${ }^{-1}$ day $^{-1}$ (Figure 6).

Twenty-seven morphospecies were captured throughout the study period, divided into six orders and twenty families (Table 2). Regarding the number of families, the order Characiformes was the most representative with eight families, followed by Siluriformes with six families and Gymnotiformes with three families. The orders Atheriniformes, Cypriniformes and Perciformes showed only one family each.

Three morphospecies of exotic fish introduced in the region were recorded in the fisheries: the African catfish (Clarias gariepinus), the carp (Aristichthys nobilis; Ctenopharingodon idellus; Cyprinus carpio) and the tilápia (Oreochromis niloticus).
The main morphospecies captured on the basis of the caught biomass were carp, traíra, mandi, jundiá, curimba, cascudo, lambari, suruvi, piranha, dourado and piava. Among the morphospecies cited, it is noteworthy that the first four together accounted for approximately $60 \%$ of the total catch during the sampling period (Figure 7).

Among migratory species, the highlight was the presence of curimba (Prochilodus lineatus), with a $7.8 \%$ share of the total catch; suruvi (Steindachneridion scriptum), with 5.4\%; dourado (Salminus brasiliensis), with $2.8 \%$; and piava (Leporinus obtusidens), with $2.4 \%$.

Regarding the individual weight of fish caught, carp, traíra and curimba had similar average weights over the years of the study, whereas the mandi and jundiá showed a small reduction in body weight (Table 3 ).

Considering the CPUE (e) of the two most common types of fishing equipment used in the region, lines and drift nets, lambari and jundiá showed an increase in catch between 2007 and 2009, whereas carp and suruvi exhib- 
Schork, G., Hermes-Silva, S. and Zaniboni-Filho, E.
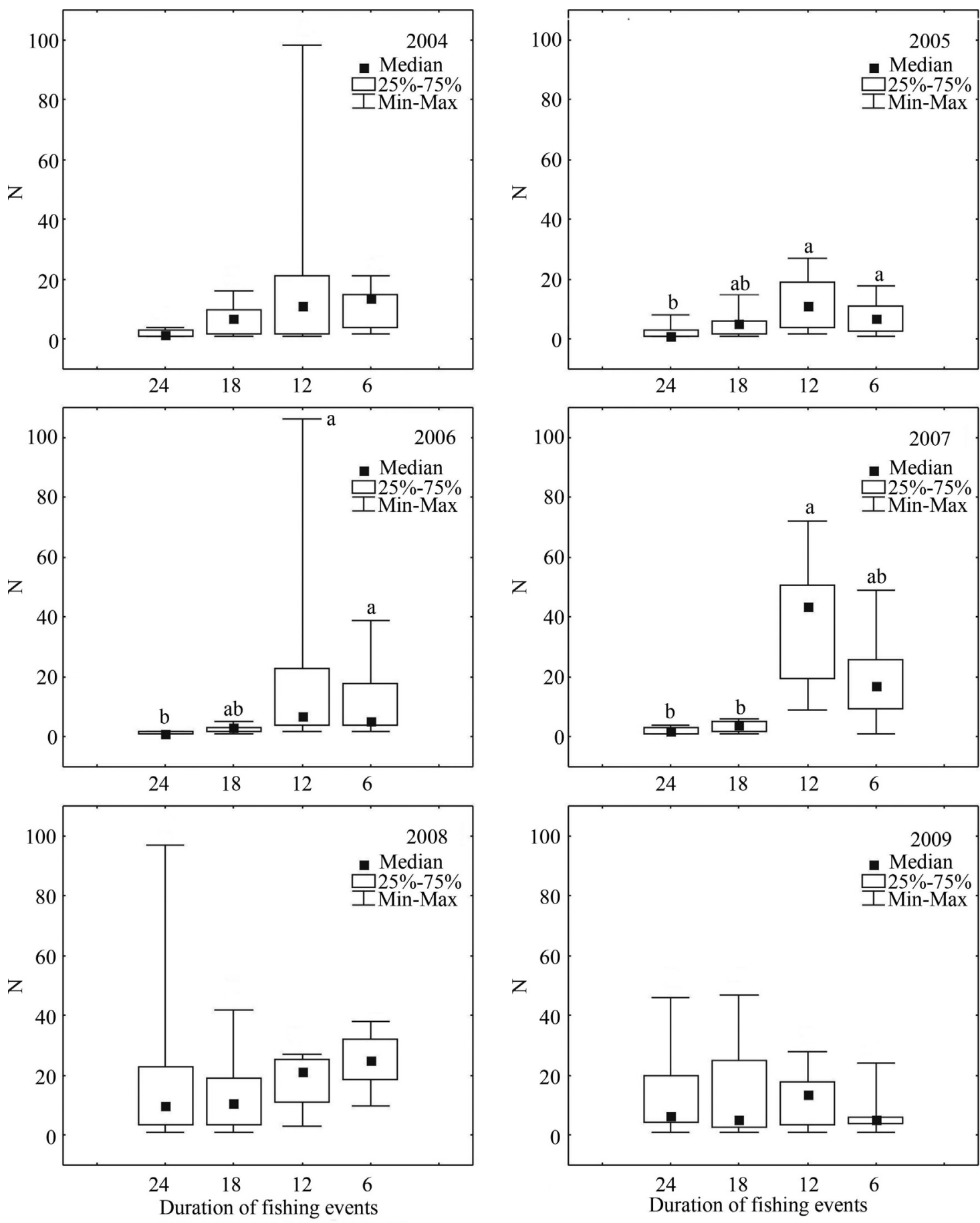

Figure 4 - Comparison of the duration of fishing events for 2004, 2005, 2006, 2007, 2008 and 2009 in the Itá reservoir. (N= number of fishing events).

ited reductions in CPUE (e) for both types of equipment (Table 4).

When fishing capture in the three compartments formed by the Itá lake were compared, the body region of the reservoir consistently maintained the highest CPUE (c) values. The compartment with the second highest
CPUE (c) changed in 2009, when values dropped in the arm compartment (Table 5).

\subsection{Socioeconomic profile}

All fishermen interviewed were male, and they were all from cities surrounding the Ita reservoir. Their age 
ranged from 22 to 75 years, but the most frequent age class (34\%) was 41 to 50 years.

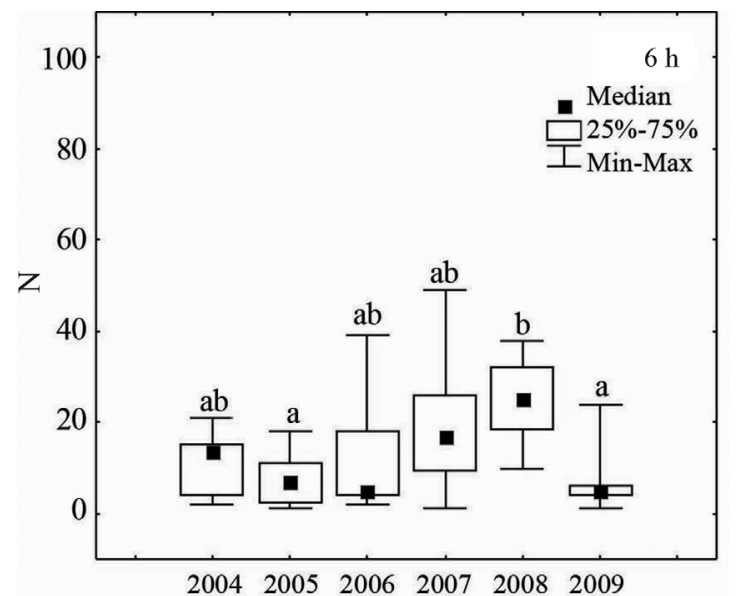

200420052006200720082009

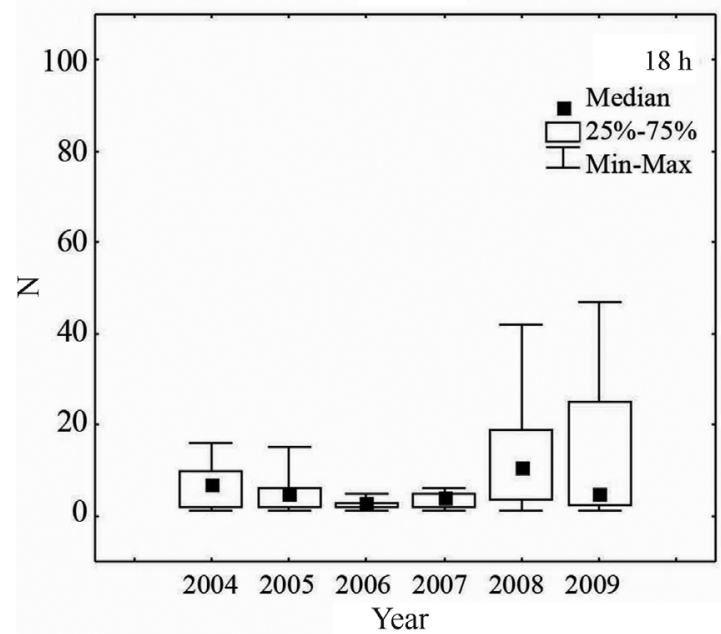

For most fishermen (88.9\%), fishing was not their main source of income; instead, they engaged in other
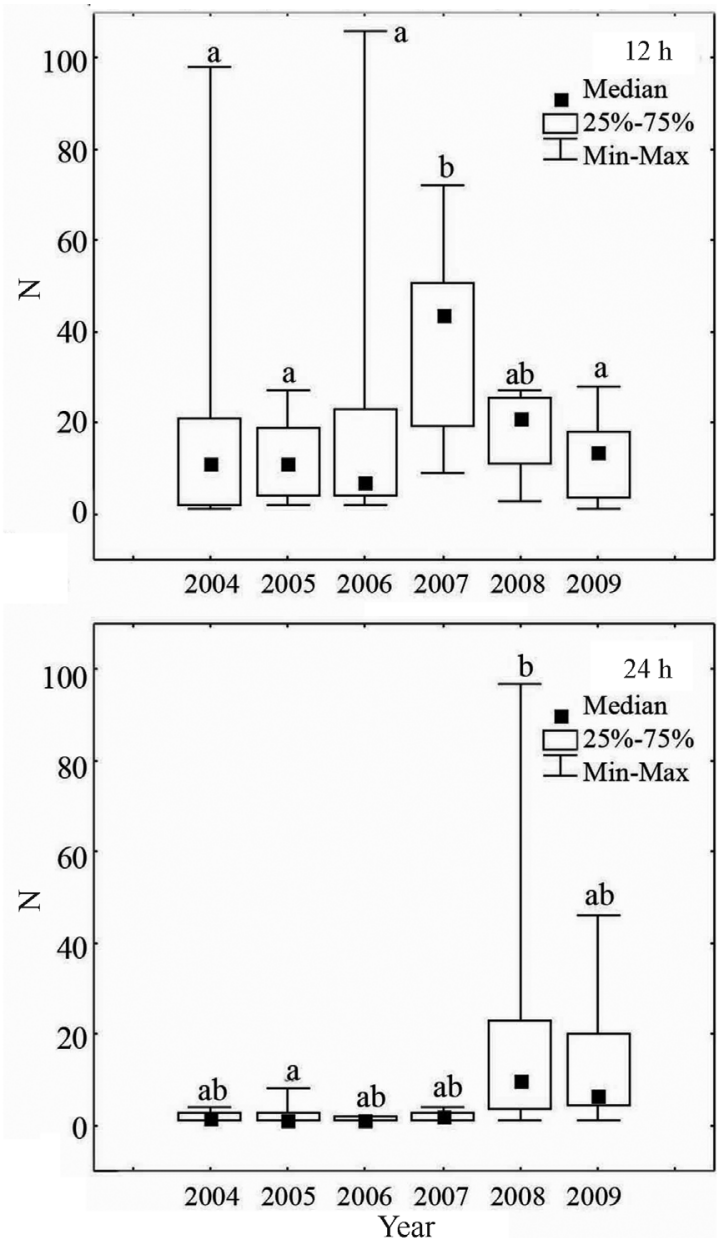

Figure 5 - Comparison of the duration of fishing events ( 6 hours, 12 hours, 18 hours and 24 hours) between the years studied in the Itá reservoir. ( $\mathrm{N}=$ number of fishing events).
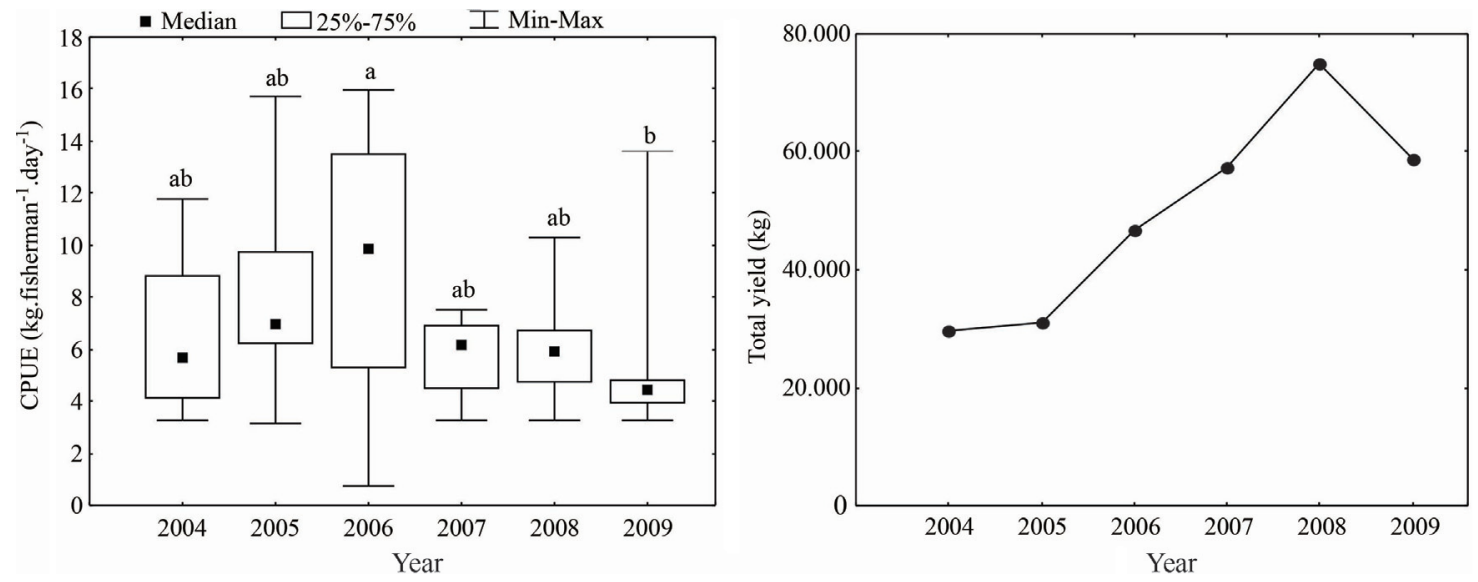

Figure 6 - CPUE (kg fisherman ${ }^{-1} \mathrm{day}^{-1}$ ) and total estimated production $(\mathrm{kg})$ of fish captured between 2004 and 2009 in the area of the HPP Itá reservoir. 
Schork, G., Hermes-Silva, S. and Zaniboni-Filho, E.

Table 2 - The twenty-seven morphospecies present in Itá reservoir and their scientific names.

\begin{tabular}{|c|c|c|c|}
\hline Ordem & Families & Morphospecies & Scientific name \\
\hline \multirow[t]{15}{*}{ Characiformes } & Curimatidae & Birú & $\begin{array}{l}\text { Steindachnerina brevipinna (Eigenmann \& Eigenmann, } \\
\text { 1889); S. biornata (Braga \& Azpelicueta, 1987) }\end{array}$ \\
\hline & Parodontidae & Canivete & Apareiodon affinis (Steindachner, 1879) \\
\hline & Prochilodontidae & $\begin{array}{l}\text { Curimba ou } \\
\text { Grumatão* }\end{array}$ & Prochilodus lineatus (Valenciennes, 1837) \\
\hline & \multirow[t]{6}{*}{ Characidae } & Dourado* & Salminus brasiliensis (Cuvier, 1816) \\
\hline & & Lambari & Astyanax spp.; Hyphessobrycon spp. \\
\hline & & Pacu & Piaractus mesopotamicus (Holmberg, 1887) \\
\hline & & Piracanjuba* & Brycon orbignyanus (Valenciennes, 1850) \\
\hline & & $\begin{array}{l}\text { Piranha ou } \\
\text { Palometa }\end{array}$ & $\begin{array}{l}\text { Serrasalmus maculatus (Kner, 1858); Pygocentrus nattereri } \\
\text { (Kner, 1858) }\end{array}$ \\
\hline & & $\begin{array}{l}\text { Peixe-cachorro ou } \\
\text { Saicanga }\end{array}$ & $\begin{array}{l}\text { Oligosarcus jenynsii (Günther, 1864); O. brevioris } \\
\text { (Menezes, 1987); Galeocharax humeralis (Valenci- } \\
\text { ennes, 1834); Cynopotamus kincaidi (Schultz, 1950) }\end{array}$ \\
\hline & Acestrorhynchidae & $\begin{array}{l}\text { Peixe-cachorro ou } \\
\text { Saicanga }\end{array}$ & Acestrorhynchus pantaneiro (Menezes, 1992) \\
\hline & Cynodontidae & $\begin{array}{l}\text { Peixe-cachorro ou } \\
\text { Saicanga }\end{array}$ & Rhaphiodon vulpinus(Spix \& Agassiz, 1829) \\
\hline & \multirow[t]{2}{*}{ Anostomidae } & Piava* & Leporinus obtusidens (Valenciennes, 1837) \\
\hline & & Voga & Schizodon nasutus (Kner, 1858) \\
\hline & \multirow[t]{2}{*}{ Erythrinidae } & Traíra & Hoplias malabaricus (Bloch, 1794) \\
\hline & & Trairão & Hoplias lacerdae (Miranda Ribeiro, 1908) \\
\hline \multirow[t]{8}{*}{ Siluriformes } & \multirow[t]{3}{*}{ Pimelodidae } & Mandi & $\begin{array}{l}\text { Parapimelodus valenciennis (Lütken, 1874); Pimelodus } \\
\text { absconditus (Azpelicueta, 1995); P. atrobrunneus (Vidal \& } \\
\text { Lucena, 1999); P. maculatus (La Cepède, 1803); } \\
\text { Iheringichthys labrosus (Lütken, 1874) }\end{array}$ \\
\hline & & Surubim* & Pseudoplatystoma corruscans (Spix \& Agassiz, 1829) \\
\hline & & Suruvi ou Bocudo* & Steindachneridion scriptum (Miranda Ribeiro, 1918) \\
\hline & Clariidae & Bagre-africano** & Clarias gariepinus (Burchell, 1822) \\
\hline & Auchenipteridae & Bagre-mole & Trachelyopterus galeatus (Linnaeus, 1766) \\
\hline & Pseudopimelodidae & Bagre-sapo & Pseudopimelodus mangurus (Valenciennes, 1835) \\
\hline & Loricariidae & Cascudo & Espécies dos gêneros Hypostomus e cf. Rhinelepis \\
\hline & Heptapteridae & Jundiá & Rhamdia quelen (Quoy \& Gaimard, 1824) \\
\hline \multirow[t]{3}{*}{ Gymnotiformes } & Sternopygidae & Peixe-espada & Eigenmannia virescens (Valenciennes, 1836) \\
\hline & Gymnotidae & Peixe-espada & Gymnotus carapo (Linnaeus, 1758); \\
\hline & Apteronotidae & Peixe-espada & $\begin{array}{l}\text { Porotergus ellisi Apteronotus ellisi (Alonso de Arámbu- } \\
\text { ru, 1957) }\end{array}$ \\
\hline Atheriniformes & Atherinopsidae & Peixe-rei & Odontesthes aff. Perugiae (Evermann \& Kendall, 1906) \\
\hline Cypriniformes & Cyprinidae & Carpa** & $\begin{array}{l}\text { Aristichthys nobilis (Richardson, 1845); Ctenopharingodon } \\
\text { idellus (Valenciennes, 1844); Cyprinus carpio (Linnaeus, } \\
\text { 1758) }\end{array}$ \\
\hline \multirow[t]{3}{*}{ Perciformes } & \multirow[t]{3}{*}{ Cichlidae } & Cará & $\begin{array}{l}\text { Geophagus brasiliensis (Quoy \& Gaimard, 1824); } \\
\text { Gymnogeophagus gymnogenys (Hensel, 1870) }\end{array}$ \\
\hline & & Joana & Crenicichla spp. \\
\hline & & Tilápia** & Oreochromis niloticus (Linnaeus, 1758) \\
\hline
\end{tabular}

* Migratory species. ** Exotic species. 
economic activities, primarily agriculture (54.7\%). Only $19.2 \%$ of the fishermen interviewed were formally registered with the Fishing General Register of the Ministry of Fishing and Aquaculture.

The fisherman's family most often consisted of three members (30.6\%), but this number varied from 1 to 8 members. Regarding level of education attained, most fishermen interviewed reported an incomplete primary and middle school education $(56.1 \%)$, followed by complete primary and middle and complete high school educations.

Fishing events occurred most often with fishermen accompanied by friends $(54.9 \%)$ or relatives $(42.3 \%)$, although a small portion used helpers $(2.8 \%)$ in the activity.

Fishing experience ranged from 3 to 64 years; however, the most frequent experience level $(30.6 \%)$ was 11 to 20 years.

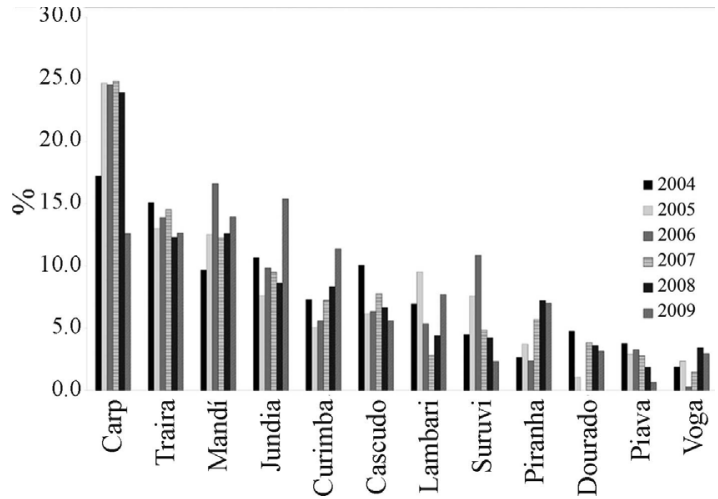

Figure 7 - Percentage of biomass captured for the most representative morphospecies in the Itá reservoir between 2004 and 2009 .

Table 3 - Number of individuals captured (No.), average individual weight (kg) and the representative percentage of total biomass of different morphospecies captured in the Itá reservoir between 2004 and 2009.

\begin{tabular}{|c|c|c|c|c|c|c|c|c|c|c|c|c|c|}
\hline \multirow{3}{*}{$\begin{array}{l}\text { Morpho } \\
\text { species }\end{array}$} & \multicolumn{12}{|c|}{ Year } & \multirow[t]{3}{*}{$\%$ total } \\
\hline & \multicolumn{2}{|c|}{2004} & \multicolumn{2}{|c|}{2005} & \multicolumn{2}{|c|}{2006} & \multicolumn{2}{|c|}{2007} & \multicolumn{2}{|c|}{2008} & \multicolumn{2}{|c|}{2009} & \\
\hline & $\mathbf{N}^{\mathbf{0}}$ & kg & $\mathbf{N}^{0}$ & kg & $\mathbf{N}^{0}$ & kg & $\mathbf{N}^{0}$ & kg & $\mathbf{N}^{\mathbf{0}}$ & kg & $\mathbf{N}^{0}$ & kg & \\
\hline B. Africano & 3 & 0.87 & 0 & 0.00 & 0 & 0.00 & 0 & 0.00 & 0 & 0.00 & 0 & 0.00 & 0.01 \\
\hline Bagre Mole & 0 & 0.00 & 0 & 0.00 & 0 & 0.00 & 0 & 0.00 & 40 & 0.05 & 0 & 0.00 & 0.00 \\
\hline Bagre Sapo & 0 & 0.00 & 14 & 3.15 & 0 & 0.00 & 1 & 4.00 & 1 & 4.00 & 0 & 0.00 & 0.06 \\
\hline Birú & 29 & 0.04 & 193 & 0.04 & 116 & 0.06 & 0 & 0.00 & 0 & 0.00 & 0 & 0.00 & 0.08 \\
\hline Canivete & 5 & 0.20 & 0 & 0.00 & 0 & 0.00 & 0 & 0.00 & 0 & 0.00 & 0 & 0.00 & 0.00 \\
\hline Cará & 47 & 0.09 & 100 & 0.09 & 15 & 0.13 & 66 & 0.07 & 144 & 0.08 & 152 & 0.09 & 0.20 \\
\hline Carpa & 104 & 3.80 & 182 & 3.27 & 253 & 3.52 & 322 & 3.44 & 384 & 3.63 & 201 & 2.58 & 21.56 \\
\hline Cascudo & 1127 & 0.21 & 763 & 0.19 & 1124 & 0.20 & 1949 & 0.18 & 1860 & 0.21 & 923 & 0.25 & 6.92 \\
\hline Curimba & 69 & 2.43 & 45 & 2.71 & 86 & 2.35 & 131 & 2.46 & 227 & 2.14 & 173 & 2.70 & 7.78 \\
\hline Dourado & 17 & 6.45 & 7 & 3.63 & 0 & 0.00 & 32 & 5.35 & 38 & 5.51 & 21 & 6.17 & 2.84 \\
\hline Joana & 5 & 0.10 & 13 & 0.11 & 35 & 0.13 & 118 & 0.10 & 234 & 0.11 & 218 & 0.11 & 0.30 \\
\hline Jundiá & 334 & 0.73 & 241 & 0.76 & 481 & 0.74 & 759 & 0.56 & 945 & 0.53 & 987 & 0.64 & 10.31 \\
\hline Lambari & 9617 & 0.02 & 13864 & 0.02 & 11684 & 0.02 & 8337 & 0.02 & 14649 & 0.02 & 19230 & 0.02 & 5.65 \\
\hline Mandi & 465 & 0.48 & 858 & 0.35 & 1257 & 0.48 & 2191 & 0.25 & 2196 & 0.33 & 1961 & 0.29 & 13.11 \\
\hline Pacu & 2 & 4.50 & 7 & 2.26 & 3 & 2.17 & 8 & 3.34 & 24 & 3.33 & 13 & 5.56 & 0.93 \\
\hline P. Cachorro & 641 & 0.15 & 685 & 0.07 & 81 & 0.17 & 27 & 0.28 & 90 & 0.10 & 105 & 0.20 & 0.85 \\
\hline P. Espada & 1 & 0.30 & 1 & 0.50 & 0 & 0.00 & 0 & 0.00 & 0 & 0.00 & 0 & 0.00 & 0.00 \\
\hline Peixe Rei & 32 & 0.08 & 77 & 0.08 & 51 & 0.08 & 70 & 0.09 & 76 & 0.06 & 64 & 0.10 & 0.13 \\
\hline Piava & 32 & 2.70 & 28 & 2.49 & 48 & 2.47 & 53 & 2.33 & 42 & 2.60 & 12 & 2.23 & 2.35 \\
\hline Piracanjuba & 0 & 0.00 & 2 & 0.71 & 2 & 0.25 & 11 & 0.62 & 16 & 1.63 & 12 & 2.98 & 0.31 \\
\hline Piranha & 201 & 0.30 & 335 & 0.27 & 287 & 0.30 & 760 & 0.33 & 1627 & 0.26 & 844 & 0.34 & 5.28 \\
\hline Surubim & 0 & 0.00 & 0 & 0.00 & 0 & 0.00 & 0 & 0.00 & 0 & 0.00 & 6 & 3.40 & 0.09 \\
\hline Suruvi & 41 & 2.52 & 69 & 2.65 & 148 & 2.66 & 91 & 2.37 & 85 & 2.88 & 36 & 2.66 & 5.44 \\
\hline Tilápia & 10 & 0.10 & 0 & 0.00 & 0 & 0.00 & 379 & 0.10 & 18 & 0.25 & 0 & 0.00 & 0.18 \\
\hline Traíra & 295 & 1.17 & 265 & 1.18 & 435 & 1.16 & 599 & 1.08 & 562 & 1.27 & 439 & 1.18 & 13.41 \\
\hline Trairão & 2 & 1.50 & 0 & 0.00 & 0 & 0.00 & 0 & 0.00 & 0 & 0.00 & 0 & 0.00 & 0.01 \\
\hline Voga & 183 & 0.24 & 226 & 0.25 & 30 & 0.35 & 292 & 0.23 & 863 & 0.23 & 484 & 0.25 & 2.19 \\
\hline
\end{tabular}


For $80.8 \%$ of the respondents, fish were caught for personal consumption; only $19.2 \%$ reported the sale of fish as the main destination. The vast majority did not receive significant income from their catch, and only three fishermen had, on average, one or two minimum wage payments per month from the sale of fish. The sale was usually made to acquaintances or neighbors, and in few cases, the production was sold to traders or middlemen who resold the fish.

All fishermen had electricity in their homes, and $84.2 \%$ had water from wells, while others had piped water $(10.5 \%)$ or capture water directly from the river $(5.3 \%)$.

\section{Discussion}

\subsection{Fishing activity}

With the characteristics of family fishing, income from sources other than fishing and fish caught primarily for personal consumption, fishing in the reservoir of Itá is best described as a subsistence activity and is based primarily on the capture of sedentary and short-distance migratory species. The CPUE and fish production values in the Itá reservoir were similar to those found in reservoirs of the Paraná Basin (Eco, 2002; Novaes and Carvalho, 2009). Despite their lower abundance, long-distance migratory species such as the dourado and curimba have remained in the catches over the years. The case of piracanjuba (Brycon orbignyanus) deserves particular attention, as the species, which was virtually gone from the upper Uruguay River and was reintroduced to the Itá reservoir through a storage program, has appeared in the catches in subsequent years.
Table 5 - CPUE (c) $\left(\mathrm{kg}\right.$ fisherman ${ }^{-1}$ day $^{-1}$ compartment $^{-1}$ ) for the three fishing compartments in the Itá reservoir.

\begin{tabular}{lccc}
\hline \multirow{2}{*}{ Fishing compartment } & \multicolumn{3}{c}{ CPUE(c) } \\
\cline { 2 - 4 } & $\mathbf{2 0 0 7}$ & $\mathbf{2 0 0 8}$ & $\mathbf{2 0 0 9}$ \\
\hline Margin & 3.69 & 3.32 & 4.58 \\
Body of the reservoir & 8.19 & 7.26 & 5.28 \\
Arm & 4.75 & 4.16 & 2.81 \\
\hline
\end{tabular}

Data on the characteristics of the vessels and equipment used are similar to data from other Brazilian reservoirs (Alves da Silva et al., 2009; Camargo et al., 2008; Mauryama et al., 2009), demonstrating that a significant portion of inland fishing in the country is still practiced with the use of low technology and small investment by the fishermen.

Estimated results for fish productivity in the Itá reservoir region $\left(3.46 \mathrm{~kg} \mathrm{ha}^{-1}\right.$ year $\left.^{-1}\right)$ were close to those found in reservoirs of the Paraná Basin, such as Água Vermelha $\left(2.1 \mathrm{~kg} \mathrm{ha}^{-1}\right.$ year $\left.^{-1}\right)$, Nova Avanhandava $\left(3.4 \mathrm{~kg} \mathrm{ha}^{-1}\right.$ year $\left.^{-1}\right)$ and Promissão (5.6 kg ha ${ }^{-1}$ year $\left.^{-1}\right)($ Eco, 2002). The reservoirs of Jurumirim $\left(15.7 \mathrm{~kg} \mathrm{ha}^{-1}\right.$ year $\left.^{-1}\right)$ (Novaes and Carvalho, 2009), Lago Paranoá (16.4 kg ha-1 year $\left.^{-1}\right)$ (Walter and Petrere Jr., 2007), and Billings (63.0 $\mathrm{kg} \mathrm{ha}^{-1}$ year $^{-1}$ ) (Minte-Vera and Petrere Jr., 2000) showed values much higher than those of the present study.

CPUE values close to those observed in this study (i.e.. between 4.64 and $9.69 \mathrm{~kg}$ fisherman ${ }^{-1}$ day $^{-1}$ ) were recorded in the reservoir of Jurumirim $(10.5 \mathrm{~kg}$ fisher$\operatorname{man}^{-1}$ day $^{-1}$ ) (Novaes and Carvalho, 2009), while higher

Table 4 - CPUE (e) values (No.fish fisherman ${ }^{-1}$ equipment $^{-1}$ day $^{-1}$ ) for lines and drift nets, the species caught in the Itá reservoir from 2007 to 2009, and comparisons showing an increase (+), decrease (-) or constancy (=) in the CPUE (e) between 2007 and 2009.

\begin{tabular}{|c|c|c|c|c|c|c|c|c|}
\hline & \multicolumn{3}{|c|}{ Line } & \multicolumn{5}{|c|}{ Drift net } \\
\hline & 2007 & 2008 & 2009 & & 2007 & 2008 & 2009 & \\
\hline Carp & 0.08 & 0.08 & 0.05 & - & 0.28 & 0.32 & 0.22 & - \\
\hline Traíra & 0.10 & 0.19 & 0.18 & + & 0.54 & 0.41 & 0.43 & - \\
\hline Mandi & 2.92 & 1.83 & 2.44 & - & 0.75 & 0.87 & 0.94 & + \\
\hline Jundiá & 0.77 & 0.97 & 1.03 & + & 0.30 & 0.26 & 0.58 & + \\
\hline Curimba & $\mathrm{nc}$ & $\mathrm{nc}$ & $\mathrm{nc}$ & & 0.11 & 0.23 & 0.14 & + \\
\hline Cascudo & 0.01 & 0.02 & 0.06 & + & 1.95 & 1.74 & 0.95 & - \\
\hline Lambari & 10.56 & 17.62 & 21.25 & + & 3.19 & 3.18 & 10.94 & + \\
\hline Suruvi & 0.02 & 0.01 & 0.01 & - & 0.08 & 0.08 & 0.04 & - \\
\hline Piranha & 0.36 & 0.62 & 0.85 & + & 0.58 & 1.07 & 0.52 & - \\
\hline Dourado & 0.002 & 0.01 & 0.002 & $=$ & 0.03 & 0.03 & 0.02 & - \\
\hline Piava & 0.04 & 0.04 & & - & 0.01 & 0.02 & 0.01 & $=$ \\
\hline Voga & 0.35 & 1.21 & 0.76 & + & 0.13 & 0.06 & 0.14 & + \\
\hline
\end{tabular}

Note: nc - no capture. 
CPUE values were recorded in the reservoirs of Billings $\left(18.9 \mathrm{~kg}\right.$ fisherman ${ }^{-1}$ day $\left.^{-1}\right)($ Alves da Silva et al., 2009), Barra Bonita $\left(66.5 \mathrm{~kg}\right.$ fisherman ${ }^{-1}$ day $\left.^{-1}\right)$, Ibitinga $\left(18.8 \mathrm{~kg}\right.$ fisherman ${ }^{-1}$ day $^{-1}$ ), Promissão (37.6 kg fisherman $^{-1}$ day $\left.^{-1}\right)$, Nova Avanhandava (29.5 kg fisherman ${ }^{-1}$ day $^{-1}$ ), and Três Irmãos (32.7 kg fisherman ${ }^{-1}$ day $^{-1}$ ) (Mauryama et al., 2009).

As demonstrated, the preferred equipment used by the fishermen remained constant over the years; therefore, any changes in the catch cannot be attributed to these characteristics. The preferred duration of fishing, when compared by year, also remained constant, indicating no further effort in this direction throughout the study.

Among the three fishing compartments, the body of the reservoir showed the highest CPUE (c), which may explain the preference of the respondents to fish there. For the arm compartment, the decrease in CPUE (c) reported in the last year of the study may explain why it was in less demand during this period. Certainly, the distance from their homes and the accessibility of the site can also influence the fishermen's preference for a given compatment.

Because the Itá reservoir is an isolated environment between the Machadinho HPP, which is located upstream, and the Itá HPP downstream, the entrance of fish from areas upstream or downstream is prevented by the dam embankments, clearly dividing the fish stocks between the users. Thus, an increase in fishing effort in areas where the free flow of fish is prevented tends to cause a reduction in CPUE. Several studies have indicated that an increase in fishing effort is a major contributor to the decline of freshwater fish stocks (Agostinho et al., 2007; Fao, 2006; King, 2007).

Regarding the abundance of species, the large numbers of lambari and cascudo caught can be attributed to their sedentary habits, which guarantee better adaptation to the conditions imposed by the lentic environment and by food availability. For fishing, however, traíra and carp, which are also sedentary, stand out for their importance in the captured biomass.

Analysis of the representative percentages of fish in the biomass captured reveal gradually increased in the participation of the jundiá and mandi morphospecies, considered to be short-distance migratory species by Zaniboni-Filho and Schulz (2003). The mandi and jundiá were the most captured morphospecies in 2009, representing $15.4 \%$ and $13.9 \%$ of the total catch, respectively. This may demonstrate that these species have found the habitats needed to complete the entire life cycle in the Itá reservoir, being able to reproduce and keep their stocks in this environment.

In this and other studies (Alves da Silva et al., 2009; Araya et al., 2009; David et al., 2006; Minte-Vera and Petrere Jr., 2000; Novaes and Carvalho, 2009; Walter and Petrere Jr., 2007), sedentary and short-distance migratory species are among the species most often captured by fishing in Brazilian reservoirs.
A striking result was observed with the piracanjuba, a long-distance migrator whose number has increased in captures over the years. In 2004, approximately 3,000 specimens of this species were released in the Itá lake by a team from the Laboratory of Biology and Cultivation of Freshwater Fish of the Federal University of Santa Catarina (Lapad/UFSC). Beginning in 2005, this species was caught by fishermen, and the number of individuals increased in the subsequent years. It is worth noting that before the release, piracanjuba had not been observed in the catches in the region for about twenty-five years (Beux and Zaniboni-Filho, 2008), corroborating the statement of Sirol and Britto (2006) that restocking programs are an important alternative for the conservation of fish species.

Other long-distance migratory species such as the suruvi, the curimba, the piava, and the dourado, although less abundant than sedentary and short-distance migratory morphospecies, have always been present in the catches. Ichthyoplankton studies carried out by Garcia et al. (2011) in the area of Itá reservoir revealed the presence of nests of dourado (Salminus brasiliensis), curimba (Prochilodus lineatus), and suruvi (Steindachneridion scriptum). Studies conducted in the region by Reynalte-Tataje and Zaniboni-Filho (2008) confirmed the presence of eggs and larvae of suruvi (Steindachneridion scriptum), jundiá (Rhamdia quelen), and some species of the mandi morphospecies (Parapimelodus valenciennis, P. maculatus, and Iheringichthys labrosus). These observations confirmed the reproduction of these species in the reservoir area and may explain their maintenance in the catches from the region several years after the formation of the Itá reservoir.

Although large migratory species were among the fish most affected by the dams (i.e. because of the decrease in the mosaic of environments used throughout their life cycle), the intensity of the impacts varies widely between dams; monitoring studies should be conducted to measure these impacts and provide information for management actions. According to Agostinho et al. (2007), the minimum section of river required for migratory fish to carry out their vital activities in full is still unknown. However, Novaes and Carvalho (2009) reported that reservoirs with free areas upstream of the dam and those that can mantain flood pulses can keep stocks of migratory species, a condition observed in the reservoir of Jurumirim. The stretch of river upstream of the Itá reservoir is only $6 \mathrm{~km}$ long; nevertheless, the spawning of suruvi has been observed in this area (Reynalte-Tataje and Zaniboni-Filho, 2008), while spawning of other migratory species has been recorded only in tributaries that flow into the Itá reservoir (Reynalte-Tataje et al., 2010).

Considering the evolution of CPUE values (e) for lambari and jundiá, the increase in catch values observed between the years 2007 and 2009 with the use of both drift net and line should be highlighted. These morphospecies have been successful in the replenishment of stocks with the aging of the Itá reservoir.

Moreover, the reduction in CPUE (e) observed for carp and suruvi may indicate that these morphospecies 
are having difficulty maintaining fish stocks in the Itá reservoir. Comparisons of data from the biomass with the number of individuals captured in 2009 show a decrease in the catch of carp, regardless of the equipment used. Of note, although the carp morphospecies is composed of exotic species, the suruvi is a native species listed in the red book of Brazilian fauna threatened with extinction (Machado et al., 2008).

\subsection{Socioeconomic profile}

In this study, all fishermen were male, a statistic that agrees with the registry of the General Fishing Commission of the MPA (2011), which indicates that $89 \%$ of registered fishermen in this region are men. The homogeneity of gender and age in this study with those of other studies (Mauryama et al., 2009; Alves da Silva et al., 2009; Araya et al., 2009; Petrere Jr. et al., 2006) demonstrates a common profile for those who practice smallscale inland fishing.

Fish caught in the region of Itá reservoir are mainly intended for personal consumption, similar to practices observed in other Brazilian reservoirs (Alves da Silva et al., 2009; Okada et al., 1997; Mauryama et al., 2009). When it occurs, the sale of fish is normally conducted in the residence of the fishermen, and the buyers are people from the community or the region. Because fishing is not the main source of income for most local fishermen, according to Fao classification (1995) the activity is considered subsistence fishing, mainly producing food for the fishermen, their families and the nearby community. In this type of fishing, the product has increased importance as an alternative protein because the main source of income comes from other activities. Because of the local characteristics of the region around the Itá reservoir, agriculture is the main source of income for fishermen.

The finding that most fishermen in this study had not completed even elementary school was also observed in the studies of Araya et al. (2009), Mauryama et al. (2009), Okada et al. (1997), Alves da SILVA et al. (2009), and Ceregato and Petrere (2002), The educational level of fishermen tends to exhibit an inverse relation to their age. This condition can be explained by the change in political and educational cultures in the region over the years. Formerly, in addition to the low value given to formal education, residents of rural areas often had limited access to primary education and needed to move to urban areas to continue their studies.

Family fishing has also been observed in other regions studied (Araya et al., 2009; Alves da Silva et al., 2009; Novaes and Carvalho, 2009; Mauryama et al., 2009), with wives, children, siblings and friends performing labor. Fishermen with more than eleven years of experience comprised the vast majority of those fishing in the Itá region, a pattern commonly observed in smallscale Brazilian fishing activity (Alves da Silva et al., 2009; Mauryama et al., 2009).

\section{Final Remarks}

The results presented here should be integrated with a continuous monitoring of fishing activity in the Itá reservoir. Only through long-term studies of fishing activity can we provide more precise information about the adaptation and development of fish species in this new environment, as well as evaluate the success of any fishing management programs implemented in the region. Complementary works on environmental monitoring are also essential to provide subsidies that contribute technically to identifying local problems and generate future studies aimed at managing fishing activity as well as aquacultural spatial planning.

\section{References}

AGÊNCIA NACIONAL DE ENERGIA ELÉTRICA (BRASIL), 2008. Atlas de energia elétrica do Brasil. $2^{\text {nd }}$ ed. Brasília: Aneel. 236 p.

AGOSTINHO, AA. and GOMES, LC., 2005. O manejo da pesca em reservatórios da bacia do alto rio Paraná: avaliação e perspectivas. In NOGUEIRA, MG., HENRY, R. and JORCIN, A. (Org.). Ecologia de reservatórios: impactos potenciais. ações de manejo e sistemas em cascata. São Carlos: Rima. 23-55 p.

AGOSTINHO. AA., GOMES, LC. and PELICICE, FM., 2007. Ecologia e manejo de recursos pesqueiros em reservatórios do Brasil. Maringá: Eduem. 501 p.

AGOSTINHO, AA., PELICICE, FM. and GOMES, LC., 2008. Dams and the fish fauna of the Neotropical region: impacts and management related to diversity and fisheries. Brazilian Journal of Biology, vol. 68, no. 4, p. 1119-1132.

ALVES DA SILVA, MEP., CASRO, PMG., MARUYAMA, LS. and PAIVA, P., 2009. Levantamento da pesca e perfil socioeconômico dos pescadores artesanais profissionais no reservatório Billings. Boletim do Instituto de Pesca, vol. 35 , no. 4 , p. 531-543.

ARAYA, P., HIRT, L. and FLORES, S., 2009. Algunos aspectos de la pesqueria artisanal en el área de influencia del embalse Yacyretá. Alto río Paraná. Misiones. Argentina. Boletim do Instituto de Pesca, vol. 35, no. 2, p. 227-238.

BEUX, LF. and ZANIBONI-FILHO, E., 2008. Produção pesqueira do reservatório de Itá. Alto Rio Uruguai. In ZANIBONI-FILHO, E. and NUÑER, APO. (Org.). Reservatório de Itá: estudos ambientais. desenvolvimento de tecnologias de cultivo e conservação da ictiofauna. Florianópolis: Ufsc. p. 87-108.

CAMARGO, SAF., OKADA, EK. and PETRERE JR. M., 2008. A quantitative approach subsidize the precautionary management of the small-scale fisheries in Itaipu reservoir, Brazil. Boletim do Instituto de Pesca, vol. 34, no. 2, p. 297-302.

CEREGATO, SA. and PETRERE JR. M., 2002. Aspectos sócio-econômicos das pescarias artesanais realizadas no complexo de Urubupungá e a sua jusante no Rio Paraná. Holos Environment, vol. 2, no. 1, p. 01-24.

ECO CONSULTORIA AMBIENTAL E COMERCIO, 2002. Limnologia. ictiologia e recursos pesqueiros: período de junho 2000 a julho de 2001. São Paulo: Programas de gestão ambiental AES Tietê S/A. Promissão. 81 p.

DAVID, GS., CARVALHO, ED., NOVAES, JLC. and BIONDI, GF., 2006. A tilápia do Tietê: Desafios e contradições da pesca artesanal de tilápias nos reservatórios hiper- 
tróficos do médio rio Tietê. Panorama da Aquicultura, vol. 16 , no. 97 , p. 24-27.

FAO. 1995. Review of the State of World Fishery Resources: Inland Capture Fisheries. Roma: Fao. 63 p. FAO Fisheries Circular $n^{\circ} 885$.

FAO. 2006. El estado mundial de la pesca y la acuicultura 2006. Departamento de Pesca y Acuicultura de la FAO. Roma: Fao. 198 p.

GARCIA, V., REYNALTE-TATAJE, D., NUNES, MC., LOPES, CA., NUÑER, APO. and ZANIBONI FILHO, E., 2011. Reproduction of migratory fish in cascade reservoirs of the upper Uruguay river. Brazil. In Proceedings of the Simposio Internacional de Ecologia, 2011. São Carlos, Brasil: UFSCar. p. 417-421.

KING, M. 2007. Fisheries biology. assessment and management. $2^{\text {nd }}$. Osney Mead: Fishing New Books. 341 p.

LUIZ, EA., PETRY, AC., PAVANELLI, CS., JÚLIO JÚNIOR, HF., LATINI, JD. and DOMINGUES, VM., 2005. As assembléias de peixes de reservatórios hidrelétricos do Estado do Paraná e bacias limítrofes. In RODRIGUES, L., THOMAZ, SM., AGOSTINHO, AA. and GOMES, LC. (Org.). Biocenoses em reservatórios: padrões espaciais e temporais. São Carlos: Rima. p.169-184.

MACHADO, ABM. and DRUMMOND, APP., 2008. Livro vermelho da fauna brasileira ameaçada de extinção. $1^{\mathrm{st}}$ ed. Belo Horizonte: Fundação Biodiversitas. 1420 p.

MAURYAMA, LS., CASTRO, PMG. and PAIVA, P., 2009. Pesca artesanal no médio e baixo Tietê. São Paulo. Brasil aspectos estruturais e socioeconômicos. Boletim do Instituto de Pesca, vol. 35, no. 1, p. 61-81.

MEURER, S., 2010. Implantação de barragens no alto rio Uruguai (Brasil): influência sobre a assembleia e biologia das principais espécies de peixes. Florianópolis: Universidade Federal de Santa Catarina. 106 p. Tese de Doutorado em Aquicultura.

MINISTÉRIO DA PESCA E AQUICULTURA, 2011. Available from: http://www.mpa.gov.br/\#destaques/inscritosRGP . Access in: 25 Oct. 2011.

MINTE-VERA, CV. and PETRERE Jr., M., 2000. Artisanal fisheries in urban reservoirs: a case study from Brazil (Billings Reservoir. São Paulo metropolitan region). Fisheries Management and Ecology, vol. 7, no. 6, p. 537-549.

NOVAES, JLC. and CARVALHO, ED., 2009. Recursos pesqueiros oriundos da pesca artesanal no reservatório de Jurumirim. rio Paranapanema. alto Paraná. Brasil. Boletim do Instituto de Pesca, vol. 35, no. 4, p. 553-565.

NOVAES, JLC. and CARVALHO, ED., 2011. Artisanal fisheries in a Brazilian hypereutrophic reservoir: Barra Bonita Reservoir. Middle Tietê River. Brazilian Journal of Biology, vol. 71, no. 4, p. 821-832.
OKADA. EK., GREGORIS, J., AGOSTINHO, AA. and GOMES, LC., 1997. Diagnóstico da pesca profissional em dois reservatórios do rio Iguaçu. In AGOSTINHO, AA. and GOMES, LC. (Eds.). Reservatório de Segredo: bases ecológicas para o manejo. Maringá: Eduem. 193-316 p.

PENHA, JMF. and MATEUS, LAF., 2007. Sustainable harvest of two large predatory catfish in the Cuiaba river basin. northern Pantanal. Brazil. Brazilian Journal of Biology, vol. 67 , no. 1 , p. $81-89$.

PETRERE JR., M., WALTER, T. and MINTE-VERA, CV., 2006. Income evaluation of small scale fishers in two Brazilian urban reservoirs: Represa Billings (SP) and Lago Paranoá (DF). Brazilian Journal of Ecology, vol. 66, no. 3, p. 817-828

REYNALTE-TATAJE, DA. and ZANIBONI FILHO, E., 2008. Biologia e identificação de ovos e larvas de peixes do Alto Rio Uruguai. In ZANIBONI FILHO, E. and NUÑER, APO. (Org.). Reservatório de Itá: Estudos ambientais. desenvolvimento de tecnologias de cultivo e conservação da ictiofauna. Florianópolis: UFSC. p. 229-256.

REYNALTE-TATAJE, DA., ZANIBONI FILHO, E., NUÑER, APO. and NUNES, MC., 2010. The "el niño" and the migratory fish reproduction in a river stretch with a cascade of dams. upper Uruguai river/Brazil. In International Congress on Biology of Fish, 2010. Barcelona. p. 215.

SIROL, RN. and BRITTO, SG., 2006. Conservação e manejo da ictiofauna: repovoamento. In NOGUEIRA, MG., HENRY, R. and JORCIN, A. (Org). Ecologia de reservatórios: Impactos potenciais. ações de manejo e sistema em cascata. $2^{\text {nd }}$ São Carlos: Rima. p.275-284.

WALTER, T. and PETRERE Jr., M., 2007. The small-scale urban reservoir fisheries of Lago Paranoá. Brasília. DF. Brazil. Brazilian Journal of Biology, vol. 67, no. 1, p. 9-21.

ZANIBONI FILHO, E., NUÑER, APO., REYNALTE-TATAJE, D., HERMES-SILVA, S. and MEURER, S., 2008. Alterações espaciais e temporais da estrutura da comunidade de peixes em decorrência da implantação do reservatório de Itá (Alto Rio Uruguai). In ZANIBONI FILHO, E. and NUÑER, APO. (Org.). Reservatório de Itá: Estudos ambientais. desenvolvimento de tecnologias de cultivo e conservação da ictiofauna. Florianópolis: UFSC. p. 21-48.

ZANIBONI FILHO, E. and SCHULZ, UH., 2003. Migratory fishes of the Uruguay river. In CAROLSFELD, J., HARVEY, B., BAER, A. and ROSS, C. (Org.). Migratory fishes of the South América: biology. social importance and conservation status. Victoria: World Fisheries Trust. p. $135-168$.

ZANIBONI FILHO, E., MEURER, S., SHIBATTA, OA. and NUÑER, APO., 2004. Catálogo ilustrado de peixes do alto rio Uruguai. Florianópolis: UFSC/Tractebel Energia. $128 \mathrm{p}$. 